Jurnal

\title{
Correlation of Tumor Necrosis Factor with Left Ventricular Hypertrophy and Prehypertension in Non Diabetes Male Abdominal Obesity
}

\author{
Frans Wantania, Lucia Panda, Reggy L Lefrandt
}

Department of Cardiology and Vascular Medicine Faculty of Medicine, Sam Ratulangi University, Manado
Introduction : Left Ventricular Hypertrophy (LVH) as an independent predictor of mortality may develop in non diabetes obese. There's a role of inflammation because adipose tissue release the proinflammatory cytokines such as TNF $\alpha$. It is important to prove this inflammatory state and its impact to the healthy obese for preventing cardiovascular events in the future. Purpose of this study is to investigate correlation of TNF $\alpha$ level with LVH and Prehypertension in non diabetes abdominal obesity.

Methods : Eighty-two male abdominal obesity and non abdominal obesity subjects with no history of diabetes were recruited in this cross-sectional study. Tumor Necrosis Factor Alpha level were measured with radioimmunoassay, blood pressure measurement was taken 2 times. Left Ventricular Mass Index (LVMI) were evaluated by M-Mode and two dimension echocardiogram and value above $115 \mathrm{~g} / \mathrm{m} 2$ are indicative of $\mathrm{LVH}$.

Result : TNFa alpha level is higher in abdominal obesity group as compare to non abdominal obesity $(0,7133 \pm 0,2072 \mathrm{pg} / \mathrm{ml}$ vs $2,395 \pm \mathrm{I}, 537 \mathrm{I} \mathrm{pg} / \mathrm{ml}$, $\mathrm{p}<0,00 \mathrm{I}$ ). Most of obese subjects developed prehypertension. Subjects with prehypertension showed higher plasma TNF alpha level as compare to subject with normal blood pressure $(2,83 \pm \mathrm{I}, 649 \mathrm{pg} / \mathrm{ml}$ vs I,38 $\pm 0,3245$ $\mathrm{pg} / \mathrm{ml}, \mathrm{p}<0,00 \mathrm{I})$. We also found the LVH in $30(60 \%)$ of abdominal obesity subjects. Obese subject had larger LVMI than non obese $(|38,427 \pm 47,46|$ $\mathrm{g} / \mathrm{m} 2$ vs $90,|88+| 6,06 \mathrm{~g} / \mathrm{m} 2, \mathrm{p}<0,00 \mathrm{I})$, and correlates positively to plasma TNF alpha level $(r=0,727, p,<0,00 \mathrm{I})$.

Conclusion : High level of plasma TNF alpha is associated with left ventricular hypertrophy and prehypertension in non diabetes male abdominal obesity.

(J Kardiol Indones. 20 I3;34:23 I-6)

Keywords : TNF $\alpha, \mathrm{LVH}$, Prehypertension, Abdominal obesity 
Jurnal

Kardiologi Indonesia

J Kardiol Indones. 2013;34:23I-6

ISSN $0126 / 3773$

\title{
Hubungan antara TNF Alfa dengan Hipertrofi Ventrikel Kiri dan Prehipertensi pada Pria Non DM dengan Obesitas Sentral
}

\author{
Frans Wantania, Lucia Panda, Reggy L Lefrandt
}

Pendahuluan. Hipertrofi ventrikel kiri (HVK) sebagai prediktor mortalitas dapat terjadi pada orang obesitas non diabetes. Inflamasi memegang peranan dalam proses ini melalui pelepasan sitokin proinflamasi seperti TNF alfa. Pembuktian adanya keadaan inflamasi dan akibatnya pada orang obese yang sehat ini sangat penting dalam upaya pencegahan timbulnya penyakit kardiovaskular pada individu tersebut. Tujuan penelitian ini untuk mengetahui korelasi kadar TNF alfa dengan HVK dan prehipertensi pada obesitas sentral tanpa diabetes.

Metodologi Delapan puluh dua pria non diabetes dengan obesitas sentral dan tanpa obesitas sentral dimasukkan ke dalam penelitian potong lintang ini. Kadar TNF alfa diukur dengan menggunakan radioimunoassay dan tekanan darah diukur dua kali. Indeks massa ventrikel kiri dievaluasi menggunakan ekokardiogram 2 dimensi dan M-Mode dimana nilai lebih dari 115 $\mathrm{g} / \mathrm{m} 2$ dinyatakan sebagai hipertrofi ventrikel kiri.

Hasil Kadar TNF alfa lebih tinggi pada kelompok obesitas sentral dibandingkan dengan non obesitas sentral $(0,7133+0,2072$ $\mathrm{pg} / \mathrm{ml}$ vs 2,395+1,5371 pg/ml, $\mathrm{p}<0,001$ ). Sebagian besar kelompok obes mengalami hipertensi dimana kadar TNF alfa pada kelompok prehipertensi lebih tinggi dibandingkan dengan yang normotensi. Kami juga mendapatkan HVK pada $60 \%$ dari kelompok obesitas sentral. Kelompok ini memiliki massa ventrikel kiri lebih besar dibandingkan non obes $(138,427+47,461$ $\mathrm{g} / \mathrm{m} 2$ vs 90,188+16,06 g/m2, $\mathrm{p}<0,001)$, dan berkorelasi positif dengan kadar TNF alfa $(\mathrm{r}=0,727, \mathrm{p}<0,001)$.

Kesimpulan Kadar TNF alfa yang tinggi berhubungan dengan hipertrofi ventrikel kiri dan prehipertensi pada pria obesitas sentral tanpa diabetes.

(J Kardiol Indones. 2013;34:231-6)

Kata Kunci: TNF $\alpha, \mathrm{HVK}$, Obesitas sentral

\section{Alamat Korespondensi}

Dr. Lucia Panda, SpJP. Departemen Kardiologi dan Kedokteran Vaskular Fakultas Kedokteran Universitas Samratulangi, Manado. E-mail: agnes.lucianda@gmail.com

\section{Introduction}

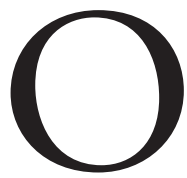

besity is steadily increasing world wide including children and adolescents. The number of overweight adolescents has doubled in the last 2-3 decades and is a major concern of public health. ${ }^{1,2}$ This state is 
associated with the significant cardiac abnormalities such as LVH and congestive heart failure. There are numerous studies suggesting that obesity is a risk factor for LVH in obese population, but the majority of these studies involved adults 3,4

In obese, adipose tissue release the proinflammatory cytokine such as TNF alpha that make LDL oxidized to ROS, had an acceleration of NO degradation result in endothelial dysfunction. ${ }^{5}$ Involvement of inflammatory markers in fibrotic process as the main component in ventricular remodelling process has previously been suggested in several studies using animal models. ${ }^{6,7}$

It is important to prove this inflammatory state and its impact to the healthy obese for preventing cardiovascular events in the future. Aim of this study is to investigate correlation of TNF $\alpha$ level with LVH and Prehypertension in non diabetes abdominal obesity

\section{Methods}

The study was performed as a cross-sectional survey on youth male with the age of 20-35 years. The sample is selected consecutively in medical student in Internal Medicine Department. Laboratory examination was done atParasitology Clinical Laboratory, Faculty of Medicine, Sam Ratulangi University, Manado after subjects signed the informed consent.

Eighty-two male abdominal obesity and non abdominal obesity subjects with no history and laboratory finding(fasting blood sugar $<100 \mathrm{mg} / \mathrm{dL}$ ) of diabetes were recruited in this cross-sectional study. Abdominal obesity is determined if $\mathrm{WC}>90 \mathrm{~cm} .{ }^{9}$ Tumor Necrosis Factor Alpha level were measured with radioimmunoassay. Blood pressure was measurement by after at least $30 \mathrm{~min}$ of rest and the average of 2 recording was used. Prehypertension if blood pressure $\geq 120 / 80 \mathrm{mmHg}$ but $<140 / 90 \mathrm{mmHg}$.

A comprehensive two-dimensional and Doppler echocardiography was performed to evaluate LVMI. Left Ventricular dimensions were measured with M-mode on-line from the parasternal projections. Left Ventricular Mass Index (LVMI) was determined from the Penn convention and value above $115 \mathrm{~g} / \mathrm{m} 2$ are indicative of LVH. ${ }^{10}$

Mann Whitney's Test was performed to know the mean's differentiation of TNF alpha and LVMI between abdominal obesity and lean groups. Odds ratio was calculated to estimate the risk of pre hypertension in high tumor necrosis factor-alpha level. Correlation between LVMI and TNF-alpha level was calculated by Spearman correlation.

\section{Result}

The characteristic of the study subjects can be seen in the Table 1. Most of subjects aged above 24-25 years TNFa alpha level is higher in abdominal obesity group.

From table 2 it can be seen that from 35 samples with Pre Hypertension 71,43\% had high TNF alpha concentration and of 26 subjects with high TNF alpha level 96,15\% had Pre Hypertension. Bivariate analysis shows the significantly higher probability of Pre Hypertension in subjects with high level of TNF alpha (Odds Ratio 5,5; CI 95 \% : 1,57 - 19,27; $\mathrm{p}=0,005)$.

We also found the LVH in $30(60 \%)$ of abdominal obesity subjects. Obese subject had larger LVMI than non obese $(138,427 \pm 47,461 \mathrm{~g} / \mathrm{m} 2$ vs $90,188 \pm 16,06$ $\mathrm{g} / \mathrm{m} 2, \mathrm{p}<0,001)$, and correlates positively to plasma TNF alpha level $(r=0,727, p,<0,001)$

Table 1. Characteristic of Sample

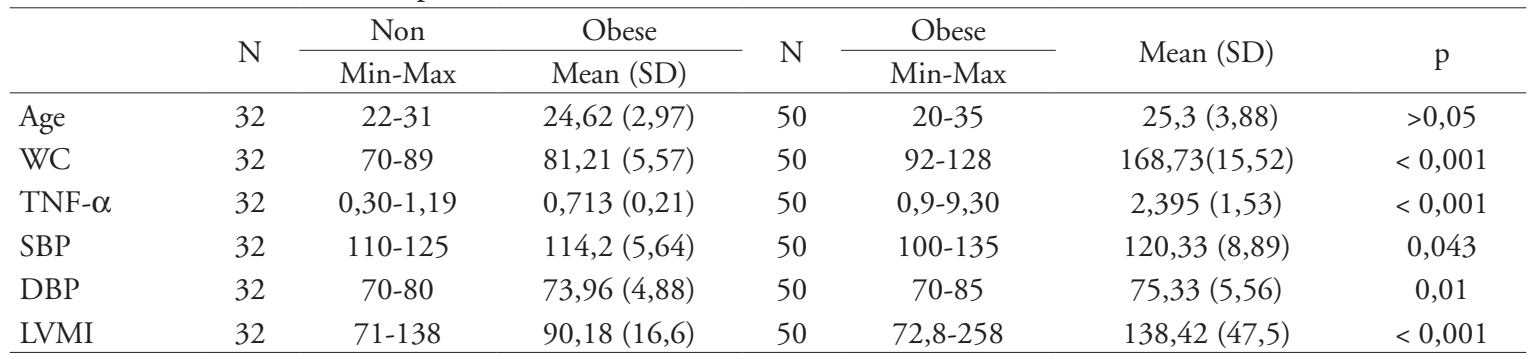


Jurnal Kardiologi Indonesia

Table 2. Association between TNF Alpha level and Pre Hypertension

\begin{tabular}{|c|c|c|c|c|c|c|c|}
\hline & \multirow{2}{*}{\multicolumn{2}{|c|}{$\begin{array}{c}\text { Pre Hypertension } \\
\text { NEGATIVE }\end{array}$}} & \multirow{2}{*}{\multicolumn{2}{|c|}{$\begin{array}{c}\text { Pre Hypertension } \\
\text { POSITIVE }\end{array}$}} & \multirow{3}{*}{ OR } & \multirow{3}{*}{ CI $95 \%$} & \multirow{3}{*}{$\mathrm{P}$} \\
\hline & & & & & & & \\
\hline & $\mathrm{N}$ & Proportion & $\mathrm{N}$ & Proportion & & & \\
\hline \multicolumn{8}{|c|}{ TNF $\alpha$ Level } \\
\hline Normal & 14 & 93,33 & 10 & 28,57 & 1 & & \\
\hline High & 1 & 6,67 & 25 & 71,43 & 5,5 & $1,57-19,27$ & 0,005 \\
\hline
\end{tabular}

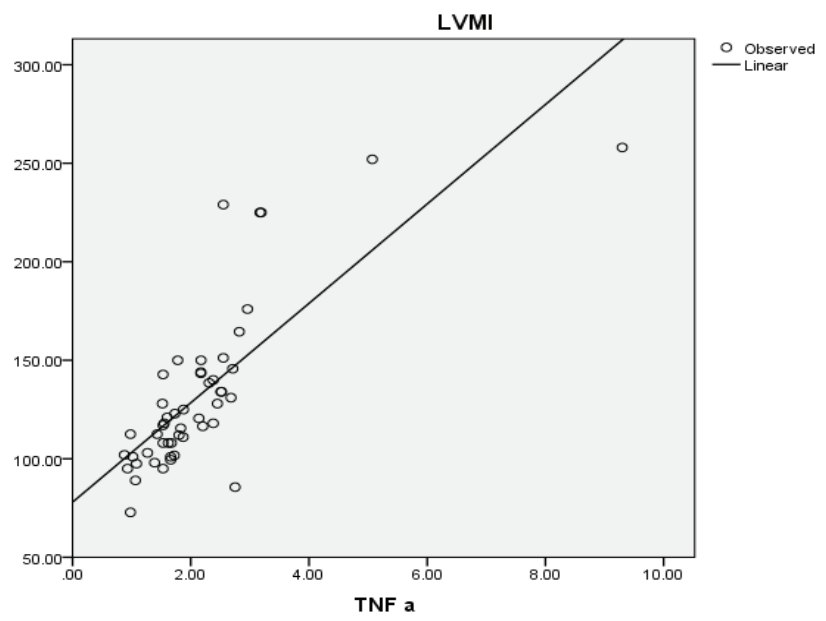

Figure 1. Correlation between LVMI and TNF Alpha Level

\section{Discussion}

In obesity, adipocytes begin to secrets low levels of TNF alpha, which can stimulate preadipocytes to produce monocyte chemoattractant protein-1 (MCP-1). In response to cytokine, endothelial cells also secrete MCP-1. Thus, either preadipocytes or endothhelial cells could be responsible for attracting macrophages to adipose tissue. ${ }^{11}$ Whatever the initial stimulus to recruit macrophages into adipose tissue is, once these cells are presents active, they, along with adipocytes and other cell types, could perpetuate a vicious cycle of macrophage recruitment, production of inflammatory cytokines, and impairment of adipocyte function. ${ }^{12}$ Previous studies reported the increase expression of TNF-alpha mRNA in the adipose tissue of obese rodents and in obese human subjects. ${ }^{13,14}$ Zahorska observed increased serum levels of TNF-alpha in obese women in comparison with lean women. Body weight reduction in obese subjects was associated with a decrease in TNF-alpha mRNA expression in fat tissue and serum. ${ }^{15}$ In this study, TNF alpha level is higher in abdominal obesity group as compare to non abdominal obesity.
Subjects with prehypertension in this study showed higher plasma TNF alpha level as compare to subject with normal blood pressure $(2,83 \pm 1,649 \mathrm{pg} / \mathrm{ml}$ vs $1,38 \pm 0,3245 \mathrm{pg} / \mathrm{ml}, \mathrm{p}<0,001)$. Of interest, the Attica study demonstrated an association between elevated TNF-alpha levels and prehypertension, even after correcting for multiple comparisons and adjusting for age, body mass index, bloodlipids, glucose, food groups consumed, and other potential confounders. ${ }^{16}$ There is also evidence to support the synthesis of TNF-a in adipose tissue. ${ }^{17}$ This may contribute to both the maintenance of a chronic low-grade inflammatory state in obese patients and to the associated comorbidities, such as hypertension. ${ }^{18}$

We suggest that endothelial dysfunction play a role in this evated blood pressure. The vascular endothelium is a major target for the action of TNF-alpha. This cytokine can decrease the release of endothelial NO and induce impairment of endothelium-dependent vasodilation in a variety of vascular beds. ${ }^{19}$ Recent evidence supports the idea that effect of TNF-alpha is $\mathrm{NO}$ dependent by producing a rapid inhibitory action on NO synthase in the endothelium via activation of a sphingomyelinase/ ceramide signaling pathway. ${ }^{20}$

Our study found the LVH in $30(60 \%)$ of abdominal obesity subjects. Obese subject had larger LVMI than non obese $(138,427 \pm 47,461 \mathrm{~g} /$ $\mathrm{m} 2$ vs $90,188 \pm 16,06 \mathrm{~g} / \mathrm{m} 2, \mathrm{p}<0,001)$, and correlates positively to plasma TNF alpha level $(r=0,727$, $\mathrm{p},<0,001)$ This result is concordant with previous studies founding increasing prevalence of $\mathrm{LVH}$ in asymptomatic obese adolescents. ${ }^{1,21}$ Increased cardiac workloads and visceral adipose tissue may contribute to the developmfetn of Left Ventricular Hypertrophy in obese subject. ${ }^{22}$ Previous studies have shown that IL-6 and TNF alpha are associated with progressive LV dysfunction, LV remodelling, myocyte hypertrophy, and myocyte apoptosis. Some mechanisms suggested for these association include immune activation, myocardial biosynthesis of inflammatory markers, underperfusion of systemic tissues, absorbtion of 
endotoxins from the edematous intestines, and neurohormonal activation. ${ }^{23}$

There is ample evidence that the accumulation of adipose tissue may determine cardiovascular alterations in several metabolic and neurohormonal pathways, causing abnormalities in sodium handling, neuroendocrine activation, the renin-angiotensinaldosterone system, and increasing myocardial oxidative stress. Change in myocardial metabolism have been demonstrated in obese patients, with a shift toward free fatty acid utilization and subsequent cardiac lipotoxicity, resulting in cardiomyocyte apoptosis. ${ }^{24,25}$

This study found a positive correlation between LVH and TNF alpha. It suggests that TNF-alpha lead to increase of LVM in abdominal obesity. TNFalpha maintains preadipocytes in an undifferentiated state while, concomitantly it is able to drive the cells toward a macrophage-like phenotype. ${ }^{26}$ TNF-alpha inhibition significantly attenuated further increases in ventricular dilatation and compliance during the remaining 4 weeks period evaluated. The hypertrophic response was also reduced significantly. ${ }^{27}$ This ctyokine also can stimulate hypertrophic growth response in cardiac myocytes. ${ }^{28}$

It is well established that TNF-alpha plays an important role in cardiac contractile dysfunction, cardiac hypertrophy, and cardiac myocyte apoptosis through reactive oxygen species and mitogen-activated protein kinase pathways, as well as through interactions with the renin-angiotensin system in experimental settings. ${ }^{29}$ Both TNFR1 and TNFR2 are expressed in most cells including cardiac myocytes. The cytoplasmic domains of TNFR1 and TNFR2 are different, and each receptor activates both distinct and overlapping intracellular signal pathways. Of these, TNFR1associated pathways contribute cardiotoxic effects including cardiac hypertrophy, whereas TNFR2associated pathways elicit cardioprotective effects. ${ }^{30}$

\section{Conclusion}

Left Ventricular Hypertrophy in non diabetes male with abdominal obesity was found in $60 \%$ of the subjects. TNF alpha level is higher in abdominal obesity group as compare to non abdominal obesity. Subjects with prehypertension showed higher plasma TNF alpha level as compare to subject with normal blood pressure. In the individual with Pre hypertension, the proportion of high tnf alpha level was $71,43 \%$ High level of plasma TNF alpha is associated with left ventricular hypertrophy and prehypertension in non diabetes male abdominal obesity.

We suggest that the inflammation state of obesity should treated immediately before develope to hypertension, diabetes, or heart failure. Weightloss by exercise regularly or antiinflammatory drugs may helpful, but needs a further investigation to confirm that.

\section{References}

1. Anderson PM, Butcher KE. Childhood obesity: trends and potential causes. Future Child 2006: 16:19-45

2. Sorof J, Daniels S. Obesity hypertension in children: a problem of epidemic proportions. Hypertension 2002; 40:441-7

3. Kenchaiah S, Evans JC, Levy D, et al. Obesity and the risk of heart faFilure. N Engl J Med 2002; 347:305-13

4. Alpert MA. Obesity cardiomyopathy: pathophysiology and evolution of the clinical syndrome. Am J Med Sci 2001; 321:225-36

5. Hajer GR, Haeften TW, and Visseren FLJ. Adipose tissue dysfunction in obesity, diabetes, and vascular diseases. Eur Heart Journal 2008; 29:2959-7

6. Kuwahara F, Kai H, Tokuda K, Nilyama H, Tahara N, Kusaba K, et al. Roles of intercellular adhesion molecule- 1 in hypertensive cardiac remodelling. Hypertension 2003; 41:819-23

7. Kuwahara K, Kai H, Tokuda K, Kai M, Takeshita A, Egashira $\mathrm{K}$, et al. Transforming growth factor beta function blocking prevents myocardial fibrosis and diastolic dysfunction in pressure-overloaded rats. Circulation 2002; 106:130-5

8. Erten Y, Tulmac M, Derici U, Pasaoglu H, Altok RK, Bali M, et al. An association between inflammatory state and left ventricular hypertrophy in hemodialysis patients. Ren Fall 2005; 27(5):581-9

9. Executive summary of the third report of the National Cholesterol Education Program (NCEP) Adult Treatment Panel III. JAMA 2001; 285:2486-97

10. Khouri MG, Peshock RM, Ayers CR, James AL, and Drazner MH. A 4-tiered classification of left ventricular hypertrophy based on left ventricular geometry. Circ Cardiovasc Imaging 2010; 3:164-71

11. Hopkins TA, Ouchi N, Shibata R, Waish K. Adiponectin actions in the cardiovascular system. Cardiovasc Res 2007;74:11-8

12. Wellen KE and Hotamisligil GS. Obesity-induced inflammatory changes in adipose tissue. J Clin Invest 2003; 112:1785-8

13. Hotamisligil GS, Arner P, Caro JF, Atkinson RL, Spiegelman BM. Increased adipose tissue expression of tumor necrosis 
factor-alpha in human obesity and insulin resistance. J Clin Invest 1995; 95:2409-15

14. Kern PA, Saghizadeh M, Ong JM, Bosch RJ, Deem R, Simsolo $\mathrm{RB}$. The expression of tumor necrosis factor in human adipose tissue. Regulation by obesity, weight loss, and relationship to lipoprotein lipase. J Clin Invest 1995; 95:2111-9

15. Zahorska B, Janowska J, Olszanecka M, and Zurakowski A. Serum concentrations of TNF-alpha and soluble TNF-alpha receptors in obesity. International Journal of Obesity 2000; 24:1392-5

16. Chrysohoou C, Pitsavos C, Panagiotakos DB, Skoumas J, Stefanadis C. Association between prehypertension status and inflammatory markers related to atherosclerotic disease: The ATTICA Study. Am J Hypertens 2004; 17: 568-73

17. Bullo M, Garcia-Lorda P, Megias I, Salas-Salvado J. Systemic inflammation, adipose tissue tumor necrosis factor, and leptin expression. Obes Res 2003; 11: 525-31.

18. Lee YH, Pratley RE. The evolving role of inflammation in obesityand the metabolic syndrome. Curr Diab Rep 2005; 5: 70-5

19. Zhang C, Xu X, Wang W, Michael L, Kuo L, and Chilian WM. TNF-alpha contributes to endothelial dysfunction in ischmia/ reperfusion injury. Arterioscler Thromb Vasc Biol 2006; 26:47580

20. Zhang DX, Yi FX, Zou AP, Li PL. Role of ceramide in TNFalpha induced impairment of endothelium-dependent vasorelaxation in coronary arteries. Am J Physiol Heart Circ Physiol 2002; 282:1785-94

21. Picchi A, Gao X, Belmadani S, Potter BJ, Foccardi M, Chilian WM, et al. Tumor necrosis factor-alpha induces endothelial dysfunction in the prediabetic metabolic syndrome. Circ Res 2006; 99:69-77

22. Palmieri V, de Simone G, Arnett DK, et al. Relation of various degrees of body mass index in patients with systemic hypertension to left ventricular mass, cardiac output, and peripheral resistance. Am J Cardiol 2001; 88:1163-8

23. Baumgarten G, Knuefermann P, Mann DL. Cytokines as emerging targets in the treatment of heart failure. Trends Cardiovasc Med 2000; 10:216-23

24. Gorzelniak K, Engeli S, Janke J, Luft FC, Sharma AM. Hormonal regulation of the human adipose-tissue renin-angiotensin system: relationship to obesity and hypertension. J Hypertens 2002; 20:965-73

25. Zhou YT, Grayburn P, Karim A, et al. Lipotoxic heart disease in obese rats: implication for human obesity. Proc Natl Acad Sci USA 2000; 97:1784-9

26. Isakson $P$, Hammarstedt $A, .$. Impaired preadipocyte differentiation in human abdominal obesity. Diabetes 2009

27. Jobe LJ, Melendez GC, Levick SP, Du Y, Brower GL, and Janicki JS. TNF-alpha inhibition attenuates adverse myocardial remodeling in a rat model of volume overload. Am J Physiol Heart Circ Physiol 2009; 297:462-8

28. Yokoyama T, Nakano M, Bednarczyk JL, et al. Tumor necrosis factor-alpha provokes a hypertrophic growth response in adult cardiac myocytes. Circulation 1997; 95:1247-52

29. Higuchi Y, Otsu K, Nishida K, Hirotani S, Nakayama H, Yamaguchi O, Matsumura Y, Ueno H, Tada M, Hori M. Involvement of reactive oxygen species-mediated NF-kappa B activation in TNF-alpha-induced cardiomyocyte hypertrophy. J Mol Cell Cardiol. 2002; 34:233-240. [PubMed: 11851362]

30. Higuchi Y, McTiernan CF, Frye CB, McGowan BS, Chan TO, Feldman AM. Tumor necrosis factor receptors 1 and 2 differentially regulate survival, cardiac dysfunction, and remodeling in transgenic mice with tumor necrosis factor-alpha-induced cardiomyopathy. Circulation. 2004; 109:1892-1897. [PubMed: 15051641 